\title{
Enzim pencernaan dan kinerja pertumbuhan ikan mas, Cyprinus carpio Linnaeus, 1758) yang diberi pakan dengan penambahan tepung kunyit Curcuma longa Linn.
}

[Digestive enzymes and growth performance of common carp, Cyprinus carpio Linnaeus, 1758 with additional of turmeric meal, Curcuma longa Linn. in the diet]

\author{
Ika Wahyuni Putri ${ }^{1} \bowtie$, Mia Setiawati ${ }^{2}$, Dedi Jusadi ${ }^{2}$ \\ ${ }^{1}$ Program Studi Ilmu Akuakultur, Sekolah Pascasarjana, Institut Pertanian Bogor \\ ${ }^{2}$ Departemen Budidaya Perairan, FPIK-IPB \\ Jl. Agatis, Kampus IPB, Dramaga, Bogor 16680 \\ Email: \\ Diterima: 08 April 2016; Disetujui: 29 November 2016
}

\begin{abstract}
Abstrak
Penelitian ini bertujuan untuk mengevaluasi pemanfaatan tepung kunyit (Curcuma longa Linn.) dengan dosis berbeda dalam pakan terhadap aktivitas enzim pencernaan dan kinerja pertumbuhan ikan mas. Tepung kunyit dengan dosis 0,1 , 2, dan 3\% dicampurkan ke dalam pakan. Pakan yang digunakan adalah pakan buatan dengan kandungan iso-protein sebesar $29,51 \pm 0,93 \%$ dan isoenergi $3948,10 \pm 68,38 \mathrm{kkal} \mathrm{kg}^{-1}$ pakan. Ikan uji yang digunakan adalah ikan mas dengan bobot sebesar 2,82 $\pm 0,04 \mathrm{~g}$, dipelihara dalam akuarium berukuran $60 \times 40 \times 35 \mathrm{~cm}^{3}$ dengan padat tebar 10 ekor pa-da setiap akuarium selama 60 hari. Ikan diberi pakan uji dengan frekuensi pemberian pakan sebanyak tiga kali dalam sehari yaitu pada pukul 08.00, 12.00, dan 16.00 WIB secara at satiation. Penyiponan dilakukan setiap hari. Air untuk budi daya diganti setiap tiga hari sekali sebanyak $25 \%$ dari volume media pemeliharaan. Rancangan yang digunakan adalah rancangan acak lengkap (RAL) dengan 4 perlakuan dan 3 ulangan. Hasil penelitian menunjukkan bahwa pemberian tepung kunyit dengan dosis $2 \%$ meningkatkan aktivitas enzim amilase dan protease yaitu $7,012 \mathrm{U} \mathrm{mg}^{-1}$ dan 0,032 $\mathrm{U} \mathrm{mg}^{-1}$. Pemberian tepung kunyit dengan dosis $2 \%$ juga meningkatkan laju pertumbuhan harian yaitu $2,22 \pm 0,13 \%$. Disimpulkan bahwa pemberian tepung kunyit dosis $2 \%$ pada pakan dapat meningkatkan enzim amilase, protease dan kinerja pertumbuhan ikan mas.
\end{abstract}

Kata penting: ikan mas, Curcuma longa Linn, enzim pencernaan, kinerja pertumbuhan,

\begin{abstract}
This study aimed to evaluate the additional of turmeric meal (Curcuma longa Linn.) with different doses in feed to digestion enzyme activities and growth performance of common carp. The turmeric meal doses i.e $0,1,2$ and $3 \%$ were mixed into fish diet. The diet was formulated diet that contain isoprotein as much as $29.51 \pm 0.93 \%$ and isoenergy $3948.10 \pm 68.38 \mathrm{kcal} \mathrm{kg}^{-1}$ diet. Common carp as sample test with initial body weight $2.82 \pm 0.04 \mathrm{~g}$ were reared in $60 \times 40 \times 35 \mathrm{~cm}^{3}$ aquarium with density of 10 fish/aquaria entire 60 days. Fishes were given diet three times daily at 08:00 am, 12:00 am, and 16:00 pm by at satiation level. Syphonization was performed every day. Water exchange was applied once every 3 days as much as $25 \%$ from rearing media volume. Experimental design was set according to completely randomized design with 4 treatments and 3 replications. The results showed that the turmeric meal with dose $2 \%$ could increased amylase and protease activities were $7.012 \mathrm{U} \mathrm{mg}^{-1}$ and $0.032 \mathrm{U} \mathrm{mg}^{-1}$. Turmeric meal with dose $2 \%$ also increased daily growth rate of common carp $2.22 \pm 0.13 \%$. Therefore, the conclusion of this study was the addition of turmeric meal with dose $2 \%$ in the diet could increased digestive enzyme activities amylase, protease and improved growth performance of common carp.
\end{abstract}

Keywords: common carp, Curcuma longa Linn, digestive enzymes, growth performance

\section{Pendahuluan}

Salah satu ikan budi daya yang digemari oleh masyarakat Indonesia adalah ikan mas $(C y$ prinus carpio). Di Indonesia, permintaan pasar akan ikan mas terus meningkat dari 282,695 ton

\footnotetext{
$\triangle$ Penulis korespondensi

Alamat surel: ika.wahyuniputri@gmail.com
}

pada tahun 2010 menjadi 484,110 pada tahun 2014 (KKP 2015). Hal ini menunjukkan budi daya ikan mas mempunyai prospek yang tinggi untuk dikembangkan. Ikan mas merupakan salah satu komoditas yang memiliki nilai ekonomis tinggi dan diproduksi dalam sistem budi daya intensif. Sistem ini memerlukan pemberian pakan 
buatan dalam jumlah cukup dan kualitas seimbang untuk meningkatkan pertumbuhan ikan. Namun budi daya ikan mas memerlukan waktu lebih dari empat bulan untuk mencapai ukuran konsumsi ( $\pm 200 \mathrm{~g})$.

Upaya meningkatkan pertumbuhan ikan mas dapat memberikan banyak manfaat seperti memperpendek waktu produksi, meningkatkan efisiensi pakan, dan meningkatkan produksi. Salah satu cara untuk meningkatkan pertumbuhan ikan mas yaitu dengan mengoptimalkan fungsi fisiologis organ tubuh ikan mas yaitu saluran pencernaan. Organ penting yang berperan dalam saluran pencernaan adalah usus karena sangat berkaitan dengan aktivitas enzim pencernaan di dalam tubuh ikan (Rojtinnakorn et al. 2012). Menurut Handayani (2006), enzim-enzim pencernaan memiliki peranan penting dalam proses pencernaan nutrien pakan. Ketersediaan enzim pencernaan akan memengaruhi efektivitas enzim dalam mencerna pakan yang diberikan, dan selanjutnya berpengaruh pada pertumbuhan. Salah satu cara untuk menstimulasi enzim pencernaan dapat lebih optimal yaitu melalui pemberian bahan alami (feed additive) kunyit (Curcuma longa Linn.).

Bahan alami merupakan bahan yang ditambahkan dalam jumlah kecil pada formulasi pakan atau pada pakan yang sudah jadi. Bahan ini memiliki fungsi untuk mempertahankan karakteristik gizi pakan, sebagai bahan pengawet, perekat atau binder, dan dapat meningkatkan nafsu makan (FAO 2006).

Kunyit (Curcuma longa Linn.) mengandung kurkumin dan minyak atsiri. Kurkumin merupakan senyawa polifenol yang terdapat pada kunyit berkisar antara 3-6\%. Menurut Sinurat et al. (2009), tepung kunyit mengandung kurkumin 9,61\% dan minyak atsiri 3,18\%. Kurkumin memiliki fungsi yang dapat merangsang dinding kantung empedu mengeluarkan cairan empedu ke dalam usus halus untuk meningkatkan pencernaan lemak, protein, dan karbohidrat sehingga aktivitas penyerapan zat-zat makanan meningkat, dan minyak atsiri pada kunyit berfungsi mencegah keluarnya asam lambung yang berlebihan sehingga kondisi lambung tidak terlalu asam dan memudahkan penyerapan zat makanan oleh usus halus (Darwis et al. 1991).

Penggunaan kunyit pada bahan pakan telah diuji oleh beberapa peneliti. Arifin (2015) melaporkan bahwa penambahan dosis ekstrak kunyit $0,15 \%$ pada pakan ikan gurame (Osphronemus gouramy) mampu meningkatkan aktivitas enzim pencernaan amilase $0,974 \mathrm{U} \mathrm{mg}^{-1}$ dan protease $10,170 \mathrm{U} \mathrm{mg}^{-1}$. Penelitian Rojtinnakorn et al. (2012) pada ikan sand goby (Oxyeleotris marmoratus) melaporkan bahwa pemberian ekstrak kunyit dengan dosis 3\% dapat meningkatkan aktivitas enzim amilase $27 \mathrm{U} \mathrm{mg}^{-1}$, lipase 2,01 U $\mathrm{mg}^{-1}$, dan tripsin $32 \mathrm{U} \mathrm{mg}^{-1}$. Selanjutnya Dewi (2015) melaporkan bahwa penambahan tepung kunyit pada pakan ikan patin siam (Pangasianodon hypopthalmus) dengan dosis pemberian (480 mg kunyit/100 g pakan) mampu meningkatkan laju pertumbuhan harian ikan patin siam. Berdasarkan hasil penelitian di atas yang memberikan peningkatan pada pertumbuhan, maka perlu dilakukan penelitian penggunaan kunyit dalam pakan ikan mas.

Penelitian ini bertujuan mengevaluasi pemanfaatan tepung kunyit dengan dosis berbeda dalam pakan terhadap aktivitas enzim pencernaan dan kinerja pertumbuhan ikan mas.

\section{Bahan dan metode}

Tempat dan waktu penelitian

Penelitian ini dilaksanakan pada bulan April-Juni 2015. Pemeliharaan hewan uji dilaku- 
kan di Laboratorium Nutrisi, Fakultas Perikanan dan Ilmu Kelautan, Institut Pertanian Bogor.

\section{Pembuatan tepung kunyit}

Rimpang kunyit (Curcuma longa Linn.) diperoleh dari Balai Penelitian Tanaman Obat dan Aromatika (BALITRO) Cimanggu, Bogor. Kunyit dibersihkan terlebih dahulu dari kotoran menggunakan air. Kunyit dikeringkan dalam oven dengan suhu $40^{\circ} \mathrm{C}$. Setelah kering, kunyit dihaluskan dengan menggunakan mesin penggiling, kemudian diayak hingga menghasilkan tepung kunyit. Selanjutnya tepung kunyit dianalisis kandungan bahan aktifnya yaitu kurkumin dan minyak atsiri. Hasil yang diperoleh kandungan kurkumin 5,50\% dan minyak atsiri 3,28\%.

\section{Pakan uji}

Pakan percobaan yang digunakan adalah pakan buatan dengan kandungan isoprotein $29,51 \pm 0,93 \%$ dan isoenergi $3948,10 \pm 68,38 \mathrm{kkal}$ $\mathrm{kg}^{-1}$ pakan. Tepung kunyit dengan dosis 0, 1, 2 dan 3\% dicampurkan ke dalam pakan. Selanjutnya bahan baku pakan ditimbang sesuai dengan formulasi yang sudah ditentukan seperti yang disajikan pada Tabel 1. Pakan dicetak dengan mesin pencetak pelet berdiameter 1-2 mm dan dioven pada suhu $40{ }^{\circ} \mathrm{C}$ selama 24 jam. Pakan uji yang sudah berbentuk pelet dianalisis proksimat untuk memastikan kandungannya sesuai dengan formulasi yang sudah dibuat (Tabel 2).

Tabel 1. Komposisi formulasi pakan uji

\begin{tabular}{lcccc}
\hline \multirow{2}{*}{ Bahan baku (\%) } & \multicolumn{4}{c}{ Penambahan tepung kunyit } \\
\cline { 2 - 5 } & $0 \%$ & $1 \%$ & $2 \%$ & 15 \\
\hline Tepung ikan & 15 & 15 & 10 & 15 \\
Tepung daging dan tulang & 10 & 10 & 25 & 10 \\
Tepung kedelai & 25 & 25 & 1 & 1 \\
Minyak ikan & 1 & 1 & 1 & 1 \\
Minyak jagung & 1 & 1 & 39 & 38 \\
Dedak gandum & 41 & 40 & 4 & 3 \\
Tapioka & 4 & 4 & 3 & 3 \\
Vitamin dan mineral & 3 & 3 & 2 & 100 \\
Tepung kunyit & 0 & 100 & 100 & 3 \\
\hline Total & 100 & & & \\
\hline
\end{tabular}

Tabel 2. Hasil analisis proksimat pakan uji yang ditambahkan tepung kunyit dengan dosis yang berbeda (\% bobot kering)

\begin{tabular}{lcccc}
\hline \multirow{2}{*}{ Kandungan nutrient } & \multicolumn{4}{c}{ Penambahan tepung kunyit } \\
\cline { 2 - 5 } & $0 \%$ & $1 \%$ & $2 \%$ & $3 \%$ \\
\hline Protein & 29,17 & 30,48 & 30,01 & 28,38 \\
Lemak & 3,61 & 3,67 & 3,59 & 3,77 \\
Abu & 13,71 & 13,46 & 13,70 & 13,01 \\
Serat kasar & 7,25 & 4,06 & 6,12 & 5,60 \\
BETN & 46,26 & 48,33 & 46,57 & 49,24 \\
GE $\left(\mathrm{kkal} \mathrm{kg}^{-1}\right)$ & 3869,53 & 4033,12 & 3927,47 & 3962,30 \\
C/P & 13,27 & 13,23 & 13,09 & 13,96 \\
\hline
\end{tabular}

Keterangan: BETN = bahan ekstrak tanpa nitrogen, GE : Gross Energy $1 \mathrm{~g}$ protein $=5,6 \mathrm{kkal} \mathrm{GE}, 1 \mathrm{~g}$ karbohidrat/BETN = 4,1 kkal GE, $1 \mathrm{~g}$ lemak = 9,4 kkal GE (Watanabe 1988). C/P: nisbah energi protein 
Persiapan wadah dan pemeliharaan ikan

Wadah pemeliharaan yang digunakan berupa akuarium berukuran $60 \times 40 \times 35 \mathrm{~cm}^{3}$ sebanyak 12 buah. Akuarium dibersihkan terlebih dahulu sebelum digunakan dengan cara dicuci, dibilas, dan dikeringkan. Pada masing-masing akuarium dilengkapi dengan top filter untuk menjaga kualitas air, thermostat untuk menjaga suhu tetap stabil dan aerator untuk menyuplai oksi-gen.

Ikan uji yang digunakan adalah ikan mas (Cyprinus carpio) dengan bobot rata-rata ikan awal sebesar 2,82 $\pm 0,04$ g sebanyak 120 ekor. Ikan uji yang digunakan diadaptasikan terlebih dahulu dengan diberi pakan komersial selama tujuh hari. Kemudian ikan dipuasakan selama satu hari sebelum ditimbang dan dimasukkan ke dalam akurium dengan padat penebaran sebanyak 10 ekor per akuarium.

Ikan dipelihara selama 60 hari dan diberi pakan uji dengan frekuensi pemberian pakan sebanyak tiga kali dalam sehari yaitu pada pukul 08.00, 12.00, dan 16.00 dengan cara at satiation. Penyiponan dilakukan setiap hari, kemudian air diisi kembali hingga ketinggian $25 \mathrm{~cm}$. Air diganti setiap tiga hari sekali sebanyak $25 \%$ dari volume media pemeliharaan. Selama masa pemeliharaan, kualitas air dijaga dalam kisaran yang layak untuk pertumbuhan ikan mas.

Oksigen terlarut diukur menggunakan alat dissolved oxygen meter (DO meter), $\mathrm{pH}$ diukur dengan menggunakan $\mathrm{pH}$ meter, dan suhu diukur secara in situ dengan menggunakan termometer. Total amonium nitrogen (TAN) diukur menggunakan spektrofotometer dengan panjang gelombang $630 \mathrm{~nm}$. Pembacaan skala di Laboratorium Lingkungan, IPB.

Penimbangan biomassa ikan mas dilakukan pada hari ke-0, ke-30, dan ke-60. Sebelum penimbangan ikan dipuasakan selama 24 jam.
Pada akhir uji pertumbuhan, 5 ekor ikan dari setiap akuarium diambil secara acak untuk dilakukan analisis proksimat tubuh.

Pengamatan biokimia darah yang terdiri atas glukosa dilakukan pada hari ke-60 pemeliharaan. Pengambilan sampel darah dilakukan dengan mengambil 5 ekor ikan secara acak pada setiap perlakuan. Sebelumnya ikan dibius dengan menggunakan stabilizer sebanyak 0,6 ppm. Sampel darah diambil dari pembuluh vena di pangkal sirip ekor menggunakan syringe yang telah dibilas dengan antikoagulan dan dimasukkan ke dalam tabung mikro. Pemisahan plasma dilakukan dengan sentrifugasi pada $2500 \mathrm{rpm}$ selama 5-20 menit dan plasma dapat langsung dianalisis atau disimpan pada suhu $-20{ }^{\circ} \mathrm{C}$ hingga digunakan.

Setelah darah ikan mas diambil, kemudian ikan mas dibedah dan diambil organ hatinya yang digunakan untuk pengamatan indeks hepatosomatik (IHS), kadar air, dan kadar lemak. Pada saat pembedahan organ, usus juga diambil untuk dianalisis enzim pencernaan meliputi enzim protease, lipase, dan amilase. Analisis enzim pencernaan dilakukan pada hari ke-0 dan hari ke60 pemeliharaan.

\section{Parameter penelitian}

Aktivitas enzim pencernaan yang diukur meliputi enzim protease metode Bergemeyer et al. (1983), enzim amilase metode Worthington (1993), dan enzim lipase metode Borlongan (1990). Rumus yang digunakan adalah sebagai berikut:

$$
\mathrm{U} / \mathrm{ml}=\frac{\text { OD sampel-OD blanko }}{\text { OD standar-OD blanko }} \times \mathrm{fp} \times \mathrm{T}
$$

Keterangan: $U=$ aktivitas dalam international unit per menit, $\mathrm{OD}=$ absorbansi, $\mathrm{fp}=$ aktor pengencer, $\mathrm{T}=$ waktu inkubasi

Jumlah konsumsi pakan merupakan jumlah pakan yang dikonsumsi oleh ikan selama pemeliharaan. Jumlah konsumsi pakan dihitung dengan cara menimbang jumlah pakan yang dikon- 
sumsi ikan setiap harinya selama masa pemeliharaan.

Laju pertumbuhan harian ikan dihitung berdasarkan persamaan yang dikemukakan oleh Huisman (1987), yaitu:

$$
\mathrm{LPH}=\left(\sqrt[\mathrm{t}]{\frac{\mathrm{Wt}}{\mathrm{Wo}}}-1\right) \times 100
$$

Keterangan: $\mathrm{LPH}=$ laju pertumbuhan harian $(\%), \mathrm{Wt}=$ bobot rata-rata ikan pada akhir pemeliharaan $(\mathrm{g}), \mathrm{Wo}=$ bobot rata-rata ikan pada awal pemeliharaan $(\mathrm{g}), \mathrm{t}=$ periode pengamatan

Efisiensi pakan dihitung menggunakan persamaan Takeuchi (1988), yaitu:

$$
E P=\frac{[(W t+W d)-W o]}{F} \times 100
$$

Keterangan: $\mathrm{EP}=$ efisiensi pakan $(\%), \mathrm{Wt}=$ biomassa ikan pada akhir pemeliharaan (g), Wo= biomassa ikan pada awal pemeliharaan $(\mathrm{g}), \mathrm{Wd}=$ biomassa ikan yang mati selama pemeliharaan $(\mathrm{g}), \mathrm{F}=$ jumlah pakan yang diberikan selama pemeliharaan $(\mathrm{g})$

Retensi protein di hitung melalui analisis proksimat protein tubuh ikan uji pada awal dan akhir penelitian. Rumus perhitungan retensi protein adalah sebagai berikut Guo et al. (2012):

$$
\mathrm{RP}=\frac{\mathrm{Pt}-\mathrm{Po}}{\mathrm{Pp}} \times 100
$$

Keterangan: $\mathrm{RP}=$ retensi protein $(\%), \mathrm{Pt}=$ jumlah protein tubuh ikan pada akhir pemeliharaan $(\mathrm{g}), \mathrm{Po}=$ jumlah protein tubuh ikan pada awal pemeliharaan $(\mathrm{g})$, $\mathrm{Pp}=$ jumlah protein pakan yang dikonsumsi ikan $(\mathrm{g})$

Retensi lemak di hitung melalui analisis proksimat lemak tubuh ikan uji pada awal dan akhir penelitian. Rumus perhitungan retensi lemak adalah sebagai berikut Guo et al. (2012):

$$
\mathrm{RL}=\frac{\mathrm{Lt}-\mathrm{Lo}}{\mathrm{Ll}} \times 100
$$

Keterangan: $\mathrm{RL}=$ retensi lemak $(\%), \mathrm{Lt}=$ jumlah lemak tubuh ikan pada akhir pemeliharaan $(\mathrm{g}), \mathrm{Lo}=$ jumlah lemak tubuh ikan pada awal pemeliharaan $(\mathrm{g}), \mathrm{Ll}=$ jumlah lemak pakan yang dikonsumsi ikan (g)

Sintasan ikan uji dihitung menggunakan rumus Asdari et al. (2011), yaitu:

$$
\mathrm{LS}=\left(\frac{\mathrm{Nt}}{\mathrm{N} 0}\right) \times 100
$$

Keterangan: $\mathrm{LS}=$ laju sintasan $(\%), \mathrm{Nt}=$ jumlah ikan pada akhir pemeliharaan, $\mathrm{No}=$ jumlah ikan pada awal pemeliharaan

Analisis indeks hepatosomatik (IHS) dilakukan pada akhir pemeliharaan. IHS diukur dengan menimbang bobot hati (g) dibandingkan dengan bobot tubuh ikan uji (g). Penimbangan dilakukan dalam keadaan bobot basah. IHS dihitung berdasarkan persamaan yang dikemukakan oleh Kiriratnikom \& Kiriratnikom (2012), yaitu:

$$
\text { IHS }=\frac{\text { Bobot organ hati }(g)}{\text { Bobot tubuh ikan uji (g) }} \times 100
$$

Kadar lemak hati didapatkan melalui analisis proksimat dengan metode Folch pada akhir penelitian AOAC (1999).

Pengukuran kadar glukosa darah dilakukan menggunakan metode GLUCOSE liquicolor (Human mbH Jerman) dengan rumus sebagai berikut:

$$
\mathrm{G}=\frac{\mathrm{As} \times \mathrm{Ksg}}{\mathrm{Asg}}
$$

Keterangan: $\mathrm{G}=$ glukosa darah $\left(\mathrm{mg} \mathrm{dL}^{-1}\right)$, As= absorbansi sampel, Ksg= konsentrasi standar glukosa, Asg= absorbansi standar glukosa

\section{Analisis data}

Rancangan yang digunakan adalah rancangan acak lengkap dengan empat perlakuan dan tiga ulangan. Parameter bobot tubuh akhir, jumlah konsumsi pakan, retensi protein, retensi lemak, laju pertumbuhan harian, efisiensi pakan, laju sintasan, aktivitas enzim pencernaan (amilase, protease, lipase), lemak hati, kadar air hati, indeks hepatosomatik, glukosa darah, kadar protein tubuh, kadar lemak tubuh, dianalisis menggunakan Microsoft Excel 2013 dan dilakukan analisis sidik ragam (ANOVA) dengan taraf kepercayaan 95\% menggunakan SPSS 16. Apabila hasil menunjukkan perbedaan yang nyata antarperlakuan maka dilakukan uji lanjut Duncan. 


\section{Hasil}

Penambahan tepung kunyit pada pakan memberikan pengaruh yang berbeda nyata terhadap aktivitas enzim amilase dan protease, namun terhadap enzim lipase tidak berbeda nyata (Tabel 3). Aktivitas enzim amilase tertinggi terdapat pada perlakuan $2 \%$ sebesar 7,012 $\mathrm{U} \mathrm{mg}^{-1}$ substrat dan terendah pada perlakuan $0 \%$ sebesar $2,945 \mathrm{U}$ $\mathrm{mg}^{-1}$ substrat, sedangkan aktivitas enzim protease tertinggi terdapat pada perlakuan $2 \%$ sebesar $0,032 \mathrm{U} \mathrm{mg}^{-1}$ substrat dan terendah pada perlakuan $0 \%$ sebesar $0,018 \mathrm{U} \mathrm{mg}^{-1}$ substrat.

Penambahan tepung kunyit pada penelitian ini terlihat memberikan pengaruh yang berbeda nyata terhadap kadar air hati dan indeks hepatosomatik (IHS). Pengaruh terhadap kadar lemak hati dan glukosa darah tidak berbeda nyata (Tabel 4).

Penambahan tepung kunyit pada ikan mas menghasilkan peningkatan biomassa ikan akhir, jumlah konsumsi pakan dan laju pertumbuhan harian. Hasil penelitian menunjukkan pada akhir pemeliharaan perlakuan tepung kunyit dengan dosis $2 \%$ memberikan pengaruh yang berbeda nyata dan menghasilkan biomassa akhir tertinggi yaitu sebesar 106,11 g, jumlah konsumsi pakan tertinggi yaitu 187,55 g dan laju pertumbuhan harian tertinggi yaitu 2,22\%. Namun tidak memberikan pengaruh yang berbeda nyata terhadap retensi protein, retensi lemak, efisiensi pakan, dan laju sintasan (Tabel 5).

Penambahan tepung kunyit memberikan pengaruh yang berbeda nyata terhadap komposisi kimiawi tubuh meliputi kandungan protein dan lemak tubuh ikan mas. Kandungan protein tertinggi diperoleh pada perlakuan tepung kunyit dengan dosis $2 \%$ yaitu sebesar $58,13 \%$ dan kadar lemak terendah diperoleh pada perlakuan dengan dosis $2 \%$ yaitu sebesar $22,11 \%$ (Tabel 6).

\section{Kualitas air}

Selama penelitian dilakukan, parameter kualitas air berada dalam kisaran layak untuk kegiatan budi daya ikan mas meliputi suhu berkisar 28-31 $1^{\circ} \mathrm{C}$, oksigen terlarut 5,1-6,7 $\mathrm{mg} \mathrm{L}^{-1}, \mathrm{pH}$ $6,97-7,72$ dan total amonium nitrogen $0,03-0,38$ $\mathrm{mg} \mathrm{L}^{-1}$.

Tabel 3. Aktivitas enzim pencernaan ikan mas yang diberi pakan perlakuan tepung kunyit dengan dosis yang berbeda selama 60 hari pemeliharaan

\begin{tabular}{lccccc}
\hline \multirow{2}{*}{$\begin{array}{c}\text { Parameter } \\
\text { (U/mg substrat) }\end{array}$} & \multirow{2}{*}{ Awal } & & \multicolumn{4}{c}{ Penambahan tepung kunyit } \\
\cline { 3 - 5 } & & $0 \%$ & $1 \%$ & $2 \%$ & $3 \%$ \\
\hline Enzim amilase & 6,32 & $2,945 \pm 0,090^{\mathrm{a}}$ & $5,509 \pm 0,367^{\mathrm{b}}$ & $7,012 \pm 0,787^{\mathrm{c}}$ & $4,572 \pm 0,756^{\mathrm{b}}$ \\
Enzim protease & 0,03 & $0,018 \pm 0,001^{\mathrm{a}}$ & $0,024 \pm 0,003^{\mathrm{a}}$ & $0,032 \pm 0,005^{\mathrm{b}}$ & $0,022 \pm 0,004^{\mathrm{a}}$ \\
Enzim lipase & 1,77 & $1,628 \pm 0,025^{\mathrm{a}}$ & $1,562 \pm 0,059^{\mathrm{a}}$ & $1,552 \pm 0,024^{\mathrm{a}}$ & $1,510 \pm 0,114^{\mathrm{a}}$ \\
\hline
\end{tabular}

Keterangan: Huruf tika atas di belakang nilai simpangan baku yang berbeda pada setiap baris menunjukkan pengaruh yang berbeda nyata $(\mathrm{P}<0,05)$.

Tabel 4. Kadar air hati, lemak hati, indeks hepatosomatik (IHS) dan glukosa darah ikan mas yang diberi pakan perlakuan tepung kunyit dengan dosis yang berbeda selama 60 hari pemeliharaan

\begin{tabular}{lcccc}
\hline \multicolumn{1}{c}{ Parameter } & \multicolumn{4}{c}{ Penambahan tepung kunyit } \\
\cline { 2 - 5 } & $0 \%$ & $1 \%$ & $2 \%$ & $3 \%$ \\
\hline Kadar air hati & $61,77 \pm 3,20^{\mathrm{a}}$ & $69,99 \pm 5,57^{\mathrm{b}}$ & $68,73 \pm 1,21^{\mathrm{b}}$ & $68,41 \pm 1,81^{\mathrm{b}}$ \\
Lemak hati & $11,79 \pm 0,90^{\mathrm{a}}$ & $10,69 \pm 2,13^{\mathrm{a}}$ & $10,21 \pm 1,74^{\mathrm{a}}$ & $8,88 \pm 1,59^{\mathrm{a}}$ \\
IHS & $0,70 \pm 0,13^{\mathrm{a}}$ & $0,89 \pm 0,10^{\mathrm{ab}}$ & $1,07 \pm 0,25^{\mathrm{b}}$ & $1,02 \pm 0,19^{\mathrm{ab}}$ \\
Glukosa & $104,38 \pm 12,31^{\mathrm{a}}$ & $111,92 \pm 14,66^{\mathrm{a}}$ & $131,51 \pm 11,92^{\mathrm{a}}$ & $124,33 \pm 19,84^{\mathrm{a}}$ \\
\hline
\end{tabular}

Keterangan: Huruf tika atas di belakang nilai simpangan baku yang berbeda pada setiap baris menunjukkan pengaruh yang berbeda nyata $(\mathrm{P}<0,05)$. 
Tabel 5. Biomassa awal $\left(\mathrm{W}_{0}\right)$, biomassa akhir (Wt), jumlah konsumsi pakan (JKP), retensi protein (RP), retensi lemak (RL), efisiensi pakan (EP), laju pertumbuhan harian (LPH), dan laju sintasan (TKH) ikan mas yang diberi pakan perlakuan tepung kunyit dengan dosis yang berbeda selama 60 hari pemeliharaan

\begin{tabular}{lcccc}
\hline \multirow{2}{*}{ Parameter } & \multicolumn{4}{c}{ Penambahan tepung kunyit } \\
\cline { 2 - 5 } & $0 \%$ & $1 \%$ & $2 \%$ & $3 \%$ \\
\hline $\mathrm{W}_{0}(\mathrm{~g})$ & $28,18 \pm 0,55^{\mathrm{a}}$ & $28,15 \pm 0,87^{\mathrm{a}}$ & $28,40 \pm 0,13^{\mathrm{a}}$ & $28,11 \pm 0,87^{\mathrm{a}}$ \\
$\mathrm{Wt}(\mathrm{g})$ & $81,31 \pm 4,97^{\mathrm{a}}$ & $93,25 \pm 3,80^{\mathrm{b}}$ & $106,11 \pm 8,22^{\mathrm{c}}$ & $98,75 \pm 4,97^{\mathrm{bc}}$ \\
$\mathrm{JKP}(\mathrm{g})$ & $138,50 \pm 1,15^{\mathrm{a}}$ & $162,60 \pm 1,93^{\mathrm{b}}$ & $187,55 \pm 11,39^{\mathrm{c}}$ & $175,75 \pm 9,32^{\mathrm{bc}}$ \\
$\mathrm{RP}(\%)$ & $18,97 \pm 1,70^{\mathrm{a}}$ & $20,97 \pm 1,37^{\mathrm{a}}$ & $21,13 \pm 1,99^{\mathrm{a}}$ & $19,95 \pm 0,81^{\mathrm{a}}$ \\
$\mathrm{RL}(\%)$ & $73,80 \pm 11,81^{\mathrm{a}}$ & $73,78 \pm 14,89^{\mathrm{a}}$ & $58,21 \pm 10,54^{\mathrm{a}}$ & $59,24 \pm 10,67^{\mathrm{a}}$ \\
LPH (\%) & $1,78 \pm 0,07^{\mathrm{a}}$ & $2,02 \pm 0,02^{\mathrm{b}}$ & $2,22 \pm 0,13^{\mathrm{c}}$ & $2,12 \pm 0,10^{\mathrm{bc}}$ \\
EP (\%) & $38,35 \pm 2,88^{\mathrm{a}}$ & $40,03 \pm 1,41^{\mathrm{a}}$ & $41,37 \pm 2,08^{\mathrm{a}}$ & $40,17 \pm 0,76^{\mathrm{a}}$ \\
TKH (\%) & $100 \pm 0^{\mathrm{a}}$ & $100 \pm 0^{\mathrm{a}}$ & $100 \pm 0^{\mathrm{a}}$ & $100 \pm 0^{\mathrm{a}}$ \\
\hline
\end{tabular}

Keterangan: Huruf tika atas di belakang nilai simpangan baku yang berbeda pada setiap baris menunjukkan pengaruh yang berbeda nyata $(\mathrm{P}<0,05)$.

Tabel 6. Kadar protein dan lemak tubuh ikan mas yang diberi pakan perlakuan tepung kunyit dengan dosis yang berbeda selama 60 hari pemeliharaan

\begin{tabular}{cccccc}
\hline \multirow{2}{*}{$\begin{array}{c}\text { Parameter } \\
(\%)\end{array}$} & \multirow{2}{*}{ Awal } & \multicolumn{4}{c}{ Penambahan tepung kunyit } \\
\cline { 3 - 6 } & & $0 \%$ & $1 \%$ & $2 \%$ & $3 \%$ \\
\hline Protein & 52,23 & $54,23 \pm 0,65^{\mathrm{a}}$ & $57,15 \pm 3,06^{\mathrm{ab}}$ & $58,13 \pm 1,77^{\mathrm{b}}$ & $55,00 \pm 1,26^{\mathrm{ab}}$ \\
Lemak & 27,08 & $26,79 \pm 1,38^{\mathrm{b}}$ & $25,73 \pm 3,01^{\text {ab }}$ & $22,11 \pm 1,90^{\mathrm{a}}$ & $23,72 \pm 1,63^{\text {ab }}$ \\
\hline
\end{tabular}

Keterangan: Kadar air pada awal pemeliharaan 73,46\%, dan akhir percobaan 0\%: 75,30\%, 1\%: 75,05\%, 2\%: 76,10, dan 3\%: 76,41\%. Huruf tika atas di belakang nilai simpangan baku yang berbeda pada setiap baris menunjukkan pengaruh yang berbeda nyata $(\mathrm{P}<0,05)$.

\section{Pembahasan}

Penambahan tepung kunyit pada pakan memengaruhi aktivitas enzim pencernaan (Tabel 3). Aktivitas enzim amilase dan protease meningkat pada ikan yang diberi tepung kunyit dosis $2 \%$ yaitu 7,012 $\mathrm{U} \mathrm{mg}^{-1}$ substrat dan $0,032 \mathrm{U} \mathrm{mg}^{-1}$ substrat. Hal ini diduga akibat zat aktif kurkumin yang terdapat pada kunyit yang dapat meningkatkan jumlah konsumsi pakan. Semakin tinggi pakan yang dikonsumsi dapat meningkatkan jumlah substrat untuk enzim, sehingga aktivitas enzim meningkat (Rojtinnakorn et al. 2012). Menurut Rungruangsak-Torrissen et al. (2009), tingginya aktivitas enzim pencernaan dapat dihubungkan dengan tingginya pakan yang dikonsumsi atau tingginya pemanfaatan pakan yang berpengaruh pada pertumbuhan somatik. Rust (2002) juga menyatakan bahwa level aktivitas spesifik enzim pencernaan lebih ditentukan oleh banyaknya pakan yang dikonsumsi sebagai substrat cerna. Hal ini sesuai dengan penelitian Arifin (2015) bahwa penambahan dosis ekstrak kunyit $0,15 \%$ pada pakan mampu meningkatkan aktivitas enzim amilase $0,974 \mathrm{U} \mathrm{mg}^{-1}$ dan protease $10,170 \mathrm{U} \mathrm{mg}^{-1}$ pada ikan gurame. Rojtinnakorn et al. (2012) juga melaporkan bahwa penambahan ekstrak kunyit dengan dosis 3\% dapat meningkatkan aktivitas enzim amilase $27 \mathrm{U} \mathrm{mg}^{-1}$, lipase $2,01 \mathrm{U} \mathrm{mg}^{-1}$, dan tripsin $32 \mathrm{U} \mathrm{mg}^{-1}$ pada ikan sand goby (Oxyeleotris marmoratus).

Nutrien yang telah dicerna kemudian akan dialirkan oleh pembuluh darah menuju hati dan digunakan untuk proses metabolisme. Kadar glukosa darah menunjukkan hasil yang tidak berbeda nyata. Arifin (2015) melaporkan bahwa penambahan dosis ekstrak kunyit sebesar $0,15 \%$ 
meningkatkan kadar glukosa darah ikan gurame. Nilai IHS yang diperoleh pada akhir penelitian meningkat seiring dengan meningkatnya dosis pakan tepung kunyit. Peningkatan IHS tersebut diduga karena meningkatnya jumlah sel hepatosit lebih banyak, sehingga ukuran hati yang lebih besar sebagai kompensasi pertumbuhan yang cepat dibandingkan dengan ikan yang mengonsumsi pakan tanpa tepung kunyit. Peningkatan IHS juga dilaporkan pada ikan gurame sebesar 1,15\% lebih tinggi dibandingkan kontrol (Arifin 2015).

Retensi nutrien tertentu pada tubuh ikan selama periode tertentu biasanya digunakan untuk mengevaluasi ketersediaan dan keseimbangan asam amino dan ketersediaan beberapa elemen esensial nutrisi lainnya (Affandi et al. 2009). Nilai retensi protein menunjukkan tidak berbeda nyata yaitu berkisar 18,97-21,13\%. Hal ini diduga oleh keseimbangan asam amino pada pakan yang diberikan kepada ikan. Menurut Ali et al. (2008), retensi protein dipengaruhi oleh berbagai faktor termasuk kandungan protein pakan, keseimbangan asam amino, dan nisbah energi pakan.

Penambahan tepung kunyit memengaruhi komposisi kimiawi tubuh akhir ikan mas yang meliputi kandungan protein dan lemak tubuh. Penambahan tepung kunyit sebesar 2\% meningkatkan kandungan protein tubuh ikan uji hingga $58,13 \%$ dan menurunkan lemak tubuh hingga $22,11 \%$ (Tabel 6). Kandungan protein tubuh dipengaruhi oleh pengambilan protein pakan dan timbunan protein yang berkorelasi positif dengan kadar protein pakan (Phumee et al. 2008). Penurunan kandungan lemak tubuh disebabkan oleh zat aktif kurkumin yang merangsang sekresi cairan empedu menjadi lebih cepat sehingga terjadi peningkatan cairan empedu yang menyebabkan kadar lemak menurun (Bintang \& Nataamijaya).
Penambahan tepung kunyit 1, 2 dan 3\% tidak berpengaruh terhadap laju sintasan ikan mas yaitu $100 \%$ untuk semua perlakuan. Namun penambahan tepung kunyit pada pakan meningkatkan nafsu makan ikan yang ditandai dengan peningkatan jumlah konsumsi pakan (Tabel 5). Peningkatan jumlah konsumsi pakan diikuti dengan meningkatnya bobot tubuh akhir dan laju pertumbuhan harian ikan mas, namun tidak diikuti dengan efisiensi pakan yang menunjukkan tidak berbeda nyata. Hal ini dikarenakan pertambahan bobot tubuh masing-masing perlakuan diimbangi oleh jumlah konsumsi pakan. Mokoginta et al. (2004) menyatakan bahwa nilai efisiensi pakan yang sama antarperlakuan disebabkan oleh pertambahan bobot tubuh masingmasing perlakuan juga diimbangi oleh jumlah konsumsi pakan. Penambahan tepung kunyit 2\% menghasilkan bobot tubuh akhir ikan dan laju pertumbuhan harian tertinggi pada ikan. Hal ini disebabkan oleh zat aktif kurkumin yang terdapat di dalam tepung kunyit bekerja secara efektif sehingga penyerapan nutrien lebih tinggi. Menurut Darwis et al. (1991), kurkumin memiliki fungsi yang dapat merangsang dinding kantung empedu untuk mengeluarkan cairan empedu ke dalam usus halus sehingga meningkatkan pencernaan lemak, protein dan karbohidrat sehingga aktivitas penyerapan zat-zat makanan meningkat. Hal ini sesuai dengan hasil penelitian Dewi (2015), bahwa penambahan tepung kunyit pada pakan ikan patin siam (Pangasianodon hypopthalmus) dengan dosis pemberian (480 mg kunyit/100 g pakan) mampu meningkatkan laju pertumbuhan harian ikan patin siam.

Peningkatan penambahan tepung kunyit hingga 3\% pada pakan menghasilkan laju pertumbuhan ikan menurun (Tabel 5). Hal ini disebabkan oleh kandungan zat anti nutrisi pada pakan. Kunyit mengandung zat antinutrisi berupa 
tannin, sehingga peningkatan persentase kunyit mengakibatkan peningkatan tannin pada pakan. Tannin dapat mengganggu proses pencernaan dengan mengikat enzim pencernaan atau kompleks komponen pakan seperti protein atau mineral, sehingga penyerapan nutrien terganggu dan pertumbuhan terhambat (NRC 2011). Hal sama juga dilaporkan oleh Rahmat \& Kusnadi (2008) bahwa penambahan tepung kunyit dengan dosis $0,1 \%$ menghasilkan penurunan pertumbuhan pada ayam yang disebabkan adanya zat antinutrisi berupa tannin.

\section{Simpulan}

Pemberian tepung kunyit dengan dosis $2 \%$ pada pakan ikan mas Cyprinus carpio meningkatkan enzim amilase 7,012 U/mg, protease $0,032 \mathrm{U} / \mathrm{mg}$ dan kinerja pertumbuhan ikan mas $2,22 \%$.

\section{Daftar pustaka}

Affandi R, Sjafei DS, Rahardjo MF, Sulistiono. 2009. Fisiologi Ikan: Pencernaan dan Penyerapan Makanan. IPB Press. Bogor. $240 \mathrm{hlm}$.

Ali A, Al-Ogaily SM, Al-Asgah NA, Goddard JS, Ahmed SI. 2008. Effect of different protein to energy $(\mathrm{P} / \mathrm{E})$ ratios on growth performance and body composition of Oreochromis niloticus fingerlings. Journal of Applied Ichtyology, 24(1): 31-37.

[AOAC] Association of Official Analytical Chemists. 1999. Official methods of analysis of AOAC Intl. 16th ed. Association of Official Analytical Chemists. Maryland (US). p. 112-115

Arifin PP. 2015. Evaluasi pemberian ekstrak kunyit Curcuma longa Linn. pada pakan terhadap enzim pencernaan dan kinerja pertumbuhan ikan gurame Osphronemus gouramy. Tesis. Program Pascasarjana Institut Pertanian Bogor. 39 hlm

Asdari R, Aliyu M, Hashim R, Ramachandran. 2011. Effect of different dietary protein and lipid source in the diet for Pangasius hypophthalmus (Sauvage, 1878) juvenile on growth performance, nutrient utilization, body indices and muscle and liver fatty acid composition. Aquaculture $\mathrm{Nu}$ trition, 17(1): 44-53.

Bergemeyer HU, Grossl M, Walter HE. 1983. Reagents for enzymatic analysis. In: Bergemeyer HU(ed.). Methods in Enzymatic Analysis. 3rd edition. Verlag Chemie, Weiheim. pp. 274-275.

Bintang IAK, Nataamijaya AG. 2006. Karkas dan lemak subkutan broiler yang mendapat pakan dengan suplementasi tepung kunyit (Curcuma domestica Val) dan tepung lempuyang (Zingiber aromaticum Val). In: Saif YM. Prosiding Seminar Nasional Teknologi Peternakan dan Veteriner. $\mathrm{Pu}-$ sat Penelitian dan Pengembangan Peternakan. p. 623-628.

Borlongan LG. 1990. Studies on the digestive lipases of milkfish, Chanos chanos. Aquaculture, 89(1-3): 315-325.

Darwis SN, Modjo Indo ABD, Hasiyah S. 1991. Tanaman Obat Familia Zingiberaccae. Badan Penelitian dan Pengembangan Pertanian Industri. Bogor. $103 \mathrm{hlm}$.

Dewi CD. 2015. Khasiat tepung kunyit (Curcuma longa) dalam pakan untuk meningkatkan performan reproduksi ikan patin siam (Pangasianodon hypopthalmus). Tesis. Program Pascasarjana Institut Pertanian Bogor. 42 hlm.

FAO (Food and Agriculture Organization)/OIE/ WHO. 2006. Joint report FAO/OIE/WHO/ Expert consultation on antimicrobial use in aquaculture and antimicrobial resistance. Food and Agriculture Organization of the United Nations. Seoul, Republic of South Korea, June 13-16.

Guo ZQ, Zhu XM, Liu JS, Han D, Yang YX, Lan ZQ, Xie SQ. 2012. Effects of dietary protein level on growth performance, nitrogen and energy budget of juvenile hybrid sturgeon (Acipenser baerii $q \times A$. gueldenstaedtii $\left.{ }^{\top}\right)$. Aquaculture. 338-341: 89-95.

Handayani S. 2006. Studi efisiensi pemanfaatan karbohidrat pakan bagi pertumbuhan ikan gurame (Osphronemus gouramy Lac.) sejalan dengan perubahan enzim pencernaan dan insulin. Tesis. Program Pascasarjana Institut Pertanian Bogor. $107 \mathrm{hlm}$.

Huisman EA. 1987. Principle of Fish Production. Department of Fish Culture and Fisheries. Wageningen Agricultural University, The Netherland. $187 \mathrm{p}$.

Kiriratnikom S, Kiriratnikom A. 2012. Growth, feed utilization, survival and body compo- 
sition of fingerlings of slender walking catfish, Clarias nieuhofii, fed diets containing different protein levels. Songklanakarin Journal of Science and Technology, 34(1): 37-43.

KKP (Kementerian Kelautan dan Perikanan). 2015. Pelepasan ikan mas mantap sebagai pendukung produksi perikanan budidaya yang berkelanjutan. www.dipb.kkp.go.id. [diunduh 26 Mei 2016].

Mokoginta I, Hapsyari F, Suprayudi MA. 2004. Peningkatan retensi protein melalui peningkatan efisiensi karbohidrat pakan yang diberi chromium pada ikan mas Cyprinus carpio Linn Jurnal Akuakultur Indonesia, 3(2): 37-41.

NRC (National Research Council). 2011. Nutrient requirement of fish and shrimp. National Academic Press. Washington DC (USA). p 376

Phumee P, Hashim R, Paiko MA, Chien ACS. 2008. Effects of dietary and lipid content on growth performance and biological indices of iridescent shark (Pangasius hypophthalamus, Sauvage 1878) fry. Aquaculture Research, 40(4): 456-463.

Rahmat A, Kusnadi E. 2008. Pengaruh penambahan tepung kunyit (Curcuma domestica Val.) dalam ransum yang diberi minyak jelantah terhadap performan ayam broiler. Jurnal Ilmu Ternak, 8(1): 25-30.

Rojtinnakorn J, Rittiplang S, Tongsiri S, Chaibu P. 2012. Tumeric extract inducing growth biomarker in sand goby (Oxyeleotris mar- moratus). 2nd International Conference on Chemical, Biological and Environment Sciences, 41-42.

Rungruangsak-Torrissen K, Stien LH, Daae BS, Vågseth $\mathrm{T}$, Thorsheim GB, Tobin D, Ritola O. 2009. Different dietary levels of protein to lipid ratio affected digestive efficiency, skeletal growth, and muscle protein in rainbow trout families. Scholarly Research Exchange, vol. 2009: 1-13.

Rust MB. 2002. Nutritional physiology In: Halver JE, Hardy RW (eds). 2002. Fish Nutrition, Third Edition. Academic Press. London. p. 367-452

Sinurat AP, Purwadaria T, Bintang IAK, Ketaren PP, Bermawie N, Raharjo M, Rizal M. 2009. The utilization of turmeric and Curcuma xanthorrhiza as feed additive for broilers. Jurnal Ilmu Ternak Veteriner, 14(2):90-96.

Takeuchi T. 1988. Laboratory work chemical evaluation of dietary nutrients. In: Watanabe T (ed). Fish Nutrition and Mariculture, Department of Aquatic Bioscience, Tokyo University of Fisheries. p 179-225.

Watanabe T. 1988. Fish Nutrition and Mariculture. JICA. Textbook. Department of Aquatic Bioscience. Tokyo University of Fisheries, Japan. 233 p.

Worthington V. 1993. Worthington Enzyme Manual. Enzymes and Related Biochemicals. Worthington Chemical Corp., New Jersey, US. 399 p. 